\title{
Teacher and Educational Fact at Multigraded Classrooms Rural Primary Schools
}

\begin{abstract}
Aynur BÍLíR*
ABSTRACT. The aim of this study is to shed into light to instruction and teaching skills of teacher in multigraded educational setting in Turkey. Multigraded classes are very common in various countries whether they are developed or underdeveloped. The hard geographical conditions and less densely populated areas bring about the multigraded educational settings as a problem. It results from the lack of teacher, student and classroom. The physical conditions and facilitations of a school with the multigraded schools affect the level of instruction deeply. The success of teaching strategies depends on the support of individualized education programs and collabarative learning settings in these classes. The teacher education programs should take into consideration for training of the teacher canditates in the lines of the realities of multigareded schools as the instruction in multigraded classe differ from normal classroom settings. The facilitations and technical support should be provided with these schools much more than the normal schools. The study proves that Ministry of National Education, Teacher Training institutions and families of the students who are in the multigraded class should collobarate extensively.
\end{abstract}

Key Words: rural areas, multigraded classes, instruction, teacher training

* Assist. Prof. Dr. Mugla University, Faculty of Education Department of Educational Sciences, Educational Administration, Planning and Economics Subject. 


\section{SUMMARY}

Multigrade Classrooms application is important for the students who are at the compulsory primary education age and lack of educational services because of geographical, economical and some other reasons. Those students get the opportunity to access to educational services and use their education right with the help of this application.

Multigrade classroom education is done in a classroom which consists of students from different grades and ages and taught by only one teacher because of lack of school, classroom, teacher or student, hardships with transportation and climate, educational necessities. Teaching at a multigrade classroom is harder than teaching at an independent classroom which has a normal educational process (MEB, 1968). This hardship can be explained with many reasons like the structure of multigrade school, conditions of surrounding, economical, social and cultural background of local people, students' level of being ready for education, in addition to managership and teaching roles, teacher's having the role of training the local people and being the leader for the solution of their problems (Ozben, 1997; Oktem, 2007). When considered the reasons, training of the teachers, who serve at multigrade classrooms, both in pre-service and in in-service process has a vital importance.

Turkey is not the only country that has multigrade classroom problem. Despite having some different reasons many developing and developed countries in the world are facing this problem (Miller, 1991). Multigrade classrooms can be seen in some developed countries (though being less) and especially widely in the under developed countries' rural areas (UNESCO, 2005). Multigrade classroom application in developed countries is not always a necessity but usually exists as a pedagogical preference or choice (Aksoy, 2008).

Many researches and experiences have proved that the success of teaching strategy at multigrade classrooms depends on support which is given to personal and group based learning and sufficient presentation of teaching materials.

According to the official statistics of Turkish National Education Ministry, 16.379 of 35.581 state schools in Turkey applied multigrade classrooms in 20042005. 587.379 students were educated and 27.685 teachers were employed in the multigraded schools (MEB, 2005a). Although teaching at multigrade classrooms application in Turkey has decreased in proportion to, it still important numeratically.

Instead of eliminating the reasons which have made the rural primary schools with multigrade classrooms and with an only teacher, experienced teachers who have been qualified for the needs of these schools must be charged, these schools must be supported with educational materials and with the help of regional education supervisors must support the teachers of these schools with counseling and assessing. In addition to these, the teacher training institutions, Turkish National Education Ministry decision making branches and parents must cooperate and apply. 


\title{
Birleștirilmiş Sınıflı Köy İlköğretim Okullarında Öğretmen ve Öğretim Gerçeği
}

\begin{abstract}
Aynur BÍLíR*
ÖZ. Bu çalışmanın temel amacı birleştirilmiş sınıflı köy ilköğretim okullarındaki öğretim ve öğretmen gerçeğini incelemektir. Birleştirilmiş sınıflar, dünyadaki pek çok gelişmiş ve gelişmekte olan ülkelerin okullarında yaygın olarak uygulanan bir modeldir. Pek çok kırsal alan eğitimcileri için, birleştirilmiş sınıflarda öğretim, bir bölgedeki ekonomik ve coğrafi şartların gerektirdiği bir zorlamadır. Öğretmen, öğrenci ve derslik sayısının yetersizliğinden kaynaklanır. Birleştirilmiş sınıflarda öğrenme ve öğretmenin durum ve koşulları onun başarısını etkilemektedir. Birleştirilmiş sınıflarda öğretim stratejilerinin başarısı, bireysel ve grup temelli öğrenmeye verilecek desteğe ve yeterli öğrenme materyallerinin sunulmasına bağlı olduğunu ortaya koymuştur. Birleştirilmiş sinıflar normal sinıflardan farklı olduğu için öğretmen eğitiminde bu konunun uygulamayla bağlantılı olarak ele alınıp işlenmesi gerekir. Birleştirilmiş sınıfları bulunan okullardaki öğretmenlerin destek hizmetler ve donanım bakımından daha fazla desteklenmelidir. Çalışmada öğretmen yetiştiren kurumlar, Milli Eğitim Bakanlığı karar örgütleri ve ailelerin birleştirilmiş sınıflı okul konusunda daha fazla işbirliği ve önlem almaları gerektiği ortaya çıkmıştır.
\end{abstract}

Anahtar Sözcükler: Kırsal alanlar, birleştirilmiş sınıflar, öğretim, öğretmen eğitimi.

${ }^{*}$ Yrd. Doç. Dr. Muğla Üniversitesi, Eğitim Fakültesi,

Eğitim Bilimleri Bölümü, Eğitim Yönetimi, Teftişi, Planlaması ve Ekonomisi ABD 


\section{GíRiș}

Toplumu oluşturan bireylerin sayısı ve ülke yüzeyine yerleşme biçimleri onların üretim gücüne katılmasını, toplumsal kaynakları paylaşmasını ve eğitim olanaklarına ulaşmasını belirleyen etkenlerdendir. Cumhuriyetin ilk yıllarında yüz kişiden sekseni köylerde yaşarken bugün tersine bir durum görülmektedir. Köylerdeki okullar boşalırken kentlerdeki okullar büyük oranda dolmaktadır. Köylerin büyük çoğunluğu küçük ve dağınık oba, kom, mezra gibi alt yerleşim birimlerinden oluşmaktadır. Yerleşim özellikleri ve nüfus azlığ 1 nedeniyle buralarda okul açma zorlaşmaktadır (Başaran,1998). Türkiye'de bu yerleşim yerlerinde çocukları eğitim olanaklarına kavuşturmak için taşımalı eğitim, yatılı ilköğretim bölge okulu (YİBO), pansiyonlu ilköğretim okulu (PİO) gibi uygulamalar yapilmaktadir.

Sekiz yıllık zorunlu eğitime geçilmesinin ardından, "Eğitimde Çă̆ Yakalama 2000 Projesi" ile ilköğretimde; \%100 okullaşma oranına ulaşılması aşamalı olarak birleştirilmiş sınıflarda öğretime son verilmesi, sınıf mevcutlarının 30'a indirilmesi, İlköğretimde niteliğin yükseltilmesi hedeflenmiştir. $\mathrm{Bu}$ hedeflere ilişkin politikalar belirlenmiş, gerekli planlamalar yapılmıştır (Kavak, 2007:113).

Birleştirilmiş sınıfların tarihi geçmişi, dünyada ve Türkiye'de oldukça eskidir. Günümüzde dünyanın az nüfuslu ve geri kalmış bölgelerinde uygulandığı halde, Türkiye'deki okulların ise yaklaşık yüzde ellisinde birleştirilmiş sınıflı uygulama devam etmektedir(MEB,2005c).

Türkiye'de birleştirilmiş sınıflar uygulamasını zorunlu kılan nedenler; öğrenci, öğretmen ve derslik sayısının yetersizliği olarak görülmektedir. Ancak bugüne kadar küçük yerleşim yerlerinde öğrenci sayısının azlığ nedeniyle gereksinim duyulan bir uygulama olarak görülmüş, akademik yönü üzerinde yeterince durulmamıştır (Karasar ve Platteau,1999).

Birleştirilmiş sınıflarda öğretim uygulaması, zorunlu ilköğretim çağında olup da coğrafi, ekonomik ve diğer nedenlerle ilköğretim hizmetlerinden yoksun kalan bireylerin bu yoksunluklarını bir ölçüde gidererek onların eğitim hizmetlerine ulaşabilmelerine ve eğitim haklarını kullanmalarına olanak sağlaması bakımından önem taşımaktadır. 1948 yılında yayınlanan İnsan Hakları Evrensel Bildirgesi'nden günümüze başlangıç düzeyinde bir eğitimi (ilköğretim veya temel eğitim) herkes için zorunlu eğitim (hak) olarak ele almış devletlere de bunu sağlama yükümlülügünü vermişti (Kavak, 2007: 69).

Eğitim ve öğretim hakkı ve ödevi, Türkiye Cumhuriyeti 1982 Anayasası'nda "sosyal ve ekonomik haklar ve ödevler" başlı̆g 1 altında ele alınmıştır. "Kimse eğitim-öğretim hakkından yoksun bırakılamaz" (mad.42) 
denilerek yurttaşların eğitim hakkı güvence altına alınmıştır. Ancak, bir hakkın yasal güvence altında olması onun hak sahipleri tarafindan kullanılıyor anlamını vermez. Diğer bir anlatımla yurttaşların eğitim özgürlüğünün tanınması eğitim hakkını sağlama açısından yeterli değildir. Eğitimin gerçekleşmesi, eğitim hakkının hak sahiplerince kullanılabilmesi için devletin edimde bulunması gerekir.(Altunya, 2003).

Devletin ödevi olan eğitim hizmetini ülkemizin özellikle kırsal alanlarındaki yerleşim birimlerine götürmenin bir yolu da birleştirilmiş sınıflı okul uygulamalarından geçmektedir. Küçük yaştaki çocuklara, ailelerinden kopmadan yaşadıkları yerde eğitim hakkını kullanma imkan ve firsatı sağlanmış olmaktadır. Türkiye'de birleştirilmiş sınıflı okulların varlığı, bu okullarda öğretim ve öğretmen gerçeğinin incelenmesini gerekli kılmaktadır.

\section{Birleştirilmiş Sınıflar}

Türkiye'de eğitimin önemi Tanzimat dönemindeki yenileşme hareketleriyle anlaşılmaya başlamıştır denilebilir. İlköğretim düzeyinde okullaşma ise 23 Nisan 1920'de Türkiye Büyük Millet Meclisi'nin açılmasından sonra önem kazanmış ve 1 Kasım 1928'de yeni Türk harflerinin kabul edilmesinden sonra başlatılan Millet Mektepleri uygulamasıyla yaygınlaşmaya başlamıştır.

1930 yılında Köy Mektepleri Müfredat Programı yürürlüğe konmuştur (T.C.Kültür Bakanlığı,1938). Bu programda, bir, iki ve üç öğretmenin bulunduğu köy okullarında ( $\mathrm{Bu}$ tarihte köy okullarında öğretim süresi üç yıldır) derslerin nasıl yürütüleceği ile ilgili esaslar belirtilmiş ve ayrıca programda örnek haftalık ders çizelgelerine yer verilmiştir (Şahin, 2007).

1939'da toplanan Birinci Milli Eğitim Şurasında köy okullarının üç yıldan beş yıla çıkarılmasıyla tek öğretmenli ve beş sınıflı köy ilkokulunda öğretim konusu ile köye öğretmen yetiştirme işi yeniden gündeme oturmuştur. Baltacıoğlu (1939) şura hazırlık dökümanı olarak hazırladığ "Tek ögrretmenli beş sinıflı ilkokul" adlı broşürde "beş sinıf talebesini toplayan, fakat ye kunu 40'ı geçmeyen bir dersaneyi tek ögretmenle idare etmek teknik bir imkândır" diyerek hem köy ilkokulunun beş y1la çıkması için olumlu görüş belirtmiş hem de birleştirilmiş sınıfta bulunması gereken en çok öğrenci sayısına dikkat çekmiştir. 17 Nisan 1940'da çıkarılan 3803 sayılı Köy Enstitüleri kanunu ile köye öğretmen yetiştirme işi özel bir önem kazanmıştır.

1946 yılında çok partili döneme girilmesi ve 1950'de iktidarın el değiştirmesi ile birlikte köye öğretmen yetiştirme politikalarnda değişiklikler olmuş ve köy enstitüleri 1954 yılında ilköğretmen okullarına dönüştürülmüştür. 1952 yılında 25 eğitimci köy eğitimi üzerine seminer 
çalışmaları yapmak ve incelemelerde bulunmak üzere bir yıllık süre ile Amerika Birleşik Devletleri'ne Florida Üniversitesine gönderilmiştir. Grup, Prof. Wofford'un nezaretinde tamamladıkları çalışmalarını raporlaştırmışlardır. Raporda "Birleştirilmiş Sınıflı Köy Okulu Program Taslağı" da yer almıştır(MEB,1954). Eğitim tarihimizin son kırk yılında birleştirilmiş sınıflarda öğretim uygulamalarında bu çalışma grubunun raporu etkin rol oynamıştır. 1965-2005 yıllarını kapsayan 40 yıllık periyotta Türkiye'deki birleştirilmiş sınıfların durumu aşağıda özetlendiği gibidir.

1965-1966 ögretim yll istatistiklerine göre Türkiye'de 30.681 ilkokul bulunmakta ve bu okullara 4.000.065 ögrenci devam etmektedir. Bu ilkokulların 27.423'ü birleştirilmiş sinıflı olup, buralarda 52.393 ögretmen çalışmakta ve 2.436 .951 öğrenci okumaktadır. Bu rakamların yüzdeleri alınınca, Türkiye'deki ilkokulların \% 90'ının birleştirilmiş sinıflı olduğu; Illkokul ögretmenlerin \% 54 'ü birleştirilmiş sinıflarda çalıştı̆̆ ve ilkokullara devam eden ögrencilerin \% 60'ının birleştirilmiş siniflı okullara devam etiği görülür (Mıhçı ve Tekışı;;1966).

2004-2005 öğretim yılında ise, Milli Eğitim Bakanlı̆̆1 (MEB, 2005a) verilerine göre Türkiye'deki 35.581 ilköğretim okulundan 16.379'u birleştirilmiş sınıflı ilköğretim okuludur. Birleştirilmiş sınıflı bu ilköğretim okullarında 587.379 öğrenci öğrenim görürken, 27.685 öğretmen görev yapmaktadır. Yine aynı dönemde zorunlu ilköğretim çağında olduğu halde yaklaşık $612.000 \mathrm{kız}$ çocuğu okul dışındadır. Bu veriler de gösteriyor ki birleştirilmiş sınıflı ilköğretim okulları ile ilgili sayı ve rakamlar 1965-1966 verilerine göre oransal olarak değişmiş olsa da birleştirilmiş sınıflarda öğretim sorunu önemini sürdürmektedir.

Bilinenin aksine birleştirilmiş sınıflarda öğretim yalnızca Türkiye'nin bir sorunu değil, nedenleri az çok farkl1lık gösterse de dünyada gelişmiş ve gelişmekte olan pek çok ülkenin yaşadığı bir sorundur. Örneğin 1918 yılında Amerika Birleşik Devletleri'nde 196.037 tek sinıflı okul olduğu ve bunun Amerika Birleşik Devletleri'ndeki bütün halk okullarının \% 70,8'ini temsil ettiğini, 1980' lere kadar tek sinıflı okul sayısının bin (1000) in altına düştüğü belirtilmektedir( Muse, Simith ve Barker 1987'den akt. Miller, 1991).

Birleştirilmiş sınıfların dünyadaki durumunu ortaya koyacak güncel ve sistematik verilere ulaşmak oldukça zordur. Aşağıda yer alan bazı ülkelerdeki sayısal veriler bunu doğrular niteliktedir.1988 yılında Avustralya'da Territories'in kuzeyindeki okulların \% 40'1 birleştirilmiş sınıftır. 2000 yılında İngiltere'de ilköğretimdeki bütün sınıfların \% 25,4'ü birleştirilmiş sınıflı okullardır. Bu okulların iki ve daha fazla düzeydeki öğrencileri bir öğretmen tarafından öğretilmektedir. Hindistan'da ise 1999 yılı verilerine göre, ilkokulların \% 84'ü üç ve daha az öğretmenlidir. Peru'da 
1998 yılında kamu ilkokullarının \% 78'i birleştirilmiş sınıflıdır. Kırsal alandaki kamu ilkokullarının \% 89,2'si birleştirilmiş sınıflı ve bu okulların \% 42'si tek öğretmenlidir (Unesco, 2005). Görüldüğü gibi birleştirilmiş sınıflarda öğretim uygulaması, az da olsa bazı gelişmiş ülkelerde ve özellikle gelişmekte olan ülkelerin kırsal bölgelerinde yaygın olarak görülmektedir.

"Yirmibirinci yüzyılda hala birleştirilmiş sınıflarda öğretim yapılır mı?" sorusuna verilecek yanıt elbette hayır olmalıdır. Ancak birleştirilmiş̧ sınıflarda öğretimi zorunlu kılan nedenler ortadan kaldırılmamış ise, diğer bir deyiş ile öğretmen ve okul sorunu çözülmemiş ise, zorunlu ilköğretim çağında olan çocuklara ilköğretim hizmetleri sağlanamamış ise, bunlar sağlanıncaya kadar, dünyada olduğu gibi bizde de birleştirilmiş sınıflarda öğretim yapmaya devam etmekten başka çözüm görünmektedir. Birleştirilmiş sınıflarda öğretimin başarısı, öğretmenin birleştirilmiş sınıfların gereksinimlerini karşılayacak nitelik ve yeterlikte yetiştirilmesinde gizlidir.

\section{Köye (Birleştirilmiş Sınıflı Köy İlköğretim Okulları İçin) Öğretmen Yetiştirme}

Birleştirilmiş sınıflarda öğretmenlik yapmak, normal öğretim yapan bağımsız sınıflara göre daha zordur. Bu zorluk; birleştirilmiş sınıflı okulun yapısı, bulunduğu çevrenin koşulları, çevre halkının ekonomik, sosyal ve kültürel yapısı, öğrencilerin eğitim öğretime hazır bulunuşluk düzeyleri ile öğretmenin yöneticilik ve öğreticilik görevinin yanı sıra yerel halkı aydınlatma, onların sorunlarının çözümünde önderlik etme gibi pek çok nedene bağlanabilir. Bu ve benzeri nedenler göz önünde bulundurulduğunda, birleştirilmiş sınıflı köy ilköğretim okullarının gereksinimlerini karşılayacak öğretmenlerin hizmet öncesinde ve hizmet içinde yetiştirilmesi yaşamsal bir öneme sahiptir.

Finlandiya gibi bazı ülkelerde birleştirilmiş sınıf öğretimi hâlihazırda öğretmen eğitimi programı içersine yerleştirilmiştir. İngiltere'de birleştirilmiş sınıf öğretmenleri, birleştirilmiş sınıflar için program desteği ve hizmet içinde yetiştirmeyi; fakat genellikle onların birleştirilmiş sınıfların istemleri ile baş etmelerini, farklılık ve farklılaşmanın ilkelerinde yetişmelerinin desteklenmesi zorunluluğunu vurgular (Berry and Little, forthcoming'den akt: Little, 2004).

Mulryan-Kyne (2006) ise birleştirilmiş sınıflarda görev yapacak öğretmenlerde bulunması gerekli bilgi beceri ve niteliklerin, şehir merkezlerindeki bağımsız sınıflarda görev yapacak öğretmenler için de gerekli ve geçerli olduğunu, öğretmenlerin bazen zorunlu bazen de isteğe bağlı olarak hem kır, hem de kent okullarında görev yapma olasılıklarının bulunduğunu, bu nedenle öğretmen yetiştirmede birleştirilmiş sınıflara özgü 
öğretmenlik bilgi, beceri ve niteliklerinin birleştirilmiş sınıflı okul ortamlarında okul yönetimi, öğretmenlik uygulaması yapılarak kazandırılması gerektiğini belirtmektedir.

Türkiye'de köye (birleştirilmiş sınıflı köy ilköğretim okulları için) öğretmen yetiştirme işi Cumhuriyetin ilk yıllarında ele alınmış ve biri 1926 yılında Denizli'de diğeri 1927 yılında Kayseri'de olmak üzere, zamanın Maarif Vekili Mustafa Necati Bey tarafindan iki köy öğretmen okulu açılmıştır (Karagöz,2005; Aydoğan, 2007). Ancak bu okulların kurucusu olan zamanın maarif vekili Mustafa Necati Bey'in ölümü üzerine yeterli ilginin gösterilmemesi, 1929 yılındaki dünya ekonomik bunalımının Türkiye üzerindeki olumsuz etkisi, öğretmen okullarından mezun olanların köylerde en az beş yıl görev yapma zorunluluğunun getirilmesi, şehir öğretmeni, köy öğretmeni ayrımının yapılması (Karagöz,2005:234) gibi nedenlerle istenilen verim alınamadığından kısa süre sora (Kayseri Zincidere 1931; Denizli 1932) kapatılmıştır. Tonguç.1947: 4008) ise, “1926'dan itibaren başlamış ve bir iki yıl içinde hız almış olan öğretmen yetiştirme işinin..duraksaması mukadderdi.... köy okullarına göre öğretmen yetiştirmeleri imkansızdı. Çünkü işbaşında bulunanların zihniyetleri, ele alınır alınmaz her biri bir firtına koparacak olan bu işlerin doğuracağ 1 zahmetlere katlanmaya müsait değildi" diyerek köy öğretmen okullarının geliştirilemeyişini ve kapatılmasının asıl nedeninin, Maarif Vekili Mustafa Necati'nin ölümünden sonra bakanlık karar kademesinde bulunan bürokratların yeterlikleriyle ilgili olduğunu belirtmektedir.

1930'lu yıllardan sora köy meselesi bir hükümet politikası haline gelmiştir. Maarif Vekili Reşit Galip'in zamanında bakanlıkta "Köy İşleri Komisyonu" kuruldu. Köyde eğitim problemi incelenmeye ve bu arada köye göre öğretmen yetiştirme konusu konuşulmaya başlandı(Tonguç,1947). Bu yıllarda Türkiye'de nüfusun yaklaşık \% 80'i köylerde yaşıyor olmasına karşın, irili ufaklı kırkbin köyden yaklaşık otuzaltı bininde okul ve öğretmen yoktur. Köyde yoksulluk, geleneklere bağl1lık ve gelişmelere karşı ilgisizlik yaygındır; kültürel ve ekonomik yönden içine kapanıktır. Kasaba ve kentler (dış dünya) ile olan ulaşım ve haberleşme olanakları zayıf; sıtma, verem başta olmak üzere bulaşıcı hastalıklar yaygın, beslenme ve barınma koşulları bozuk, bebek ölüm oranları yüksektir (Dirican, 1996). Özetle halkın büyük çoğunluğu öğrenilmiş çaresizlik içinde köylerde bulunmakta ve çok azı okuma yazma bilmektedir.

Halkı bu olumsuzluklardan kurtarmak için ilköğretimi yaygınlaştırma çabalarına girişilmiş ve öncelikle az nüfuslu köyler için eğitmen yetiştirme kurs programları deneme amaçlı olarak Eskişehir Çifteler'de ve İzmir Kızılçullu'da uygulamaya konmuştur. Sonuçların olumlu olması nedeniyle Eğitmen Kursları yurt genelinde yaygınlaştırılmıştır(Uyar,2000). 
1937-1938 öğretim yılında biri İzmir Kızılçullu'da diğeri Eskișehir Çifteler Mahmudiye'de iki Köy Öğretmen Okulu açılmıștır. Öğrencilerini köy okullarından mezun köy çocukları arasından sinavla alan bu okullar 17 Nisan 1940 y1lında köyün gereksinim duyduğu öğretmen, sağlıkçı, ebe, tarımc1, tekniker gibi iş ve meslek elemanı yetiştirmek amacıyla kurulan Köy Enstitülerinin çekirdeğini oluşturmuştur(Aydoğan,2000).

Meslek eğitiminde kabul edilen temel ve evrensel ilke; mesleği öğrenen bir adaya o mesleğin gerektirdiği kuramsal bilgileri ve uygulama becerilerinin gerçek iş ortamlarında verilmesidir. Köy enstitüleri bu ilkeye sık1 sıkıya bağlı kalarak köye öğretmen yetiştirme işini sürdürmüşlerdir. Köyden sinavla aldığı öğrencileri demokratik ortamlarda karma eğitim yoluyla bir taraftan akademik- pedagojik yönden yetiştirirken öte yandan da köy yaşamının gerektirdiği tarım ve teknik alanlarda gerekli bilgi ve becerileri kazandırarak bu kazanımlarını köy staj uygulamaları ile pekiştirerek gerçek iş koşullarına uygun yetişmiş olarak köylere gönderiyordu.

1973 tarihli ve 1739 Sayılı Milli Eğitim Temel Kanunu'nda tüm öğretim kademelerinde istihdam edilecek öğretmen adaylarının yüksek öğrenim görmeleri esası getirilmiştir. Bunun üzerine, ilköğretime sınıf öğretmeni yetiştirmek üzere 1974/1975 öğretim yılından itibaren ilköğretmen okulları bünyesinde, lise ve öğretmen liselerine dayalı iki yıllık eğitim enstitüleri açılmıştır. Eski öğretmen okulları da öğretmen liseleri haline getirilmiştir. Bu tarihten itibaren de sınıf öğretmeni olacak öğretmen adaylarının köy stajları da uygulamadan kalkmış oldu.

Yüksek Öğretim Kurumu'nun (YÖK) kurulması ve öğretmen yetiştiren kurumların üniversiteye devredilmesiyle öğretmen yetiştirmede temel alınan genel kültür ve alan bilgisi konularında yeterli bir yetişme görülürken, pedagojik formasyon, okul idereciliği ve öğretmenlik uygulamasi konularındaki yetiştirmelerin çok yeterli olmadığı ve kurumlar arasına yetiştirme farklılıkları görülmekteydi. $\mathrm{Bu}$ yetersizlikleri gidermek, farklılıkları ortadan kaldırarak öğretmen yetiştirmede ortak bir standart geliştirmek için, Milli Eğitim Bakanlığı, Yüksek Öğretim Kurulu (YÖK) ve Dünya Bankası işbirliği ile 1997 yılında eğitim fakülteleri yeniden yapılandırılmıştır. $\mathrm{Bu}$ yeniden yapılandırmada öğretmen yetiştirme modeli olarak İngiltere ve Amerika Birleşik Devletleri (Florida) modellerinin ağırlıklı olarak benimsenmesi, Üniversitelerin ve dolaysıyla eğitim fakültelerinin gelişmişlik düzeylerine bakılmaksızın öğretmen yetiştirme programlarının açılmasına, kontenjanların arttırılmasına, I. ve II. Öğretim yapılmasına izin verilmesi öğretmen yetiştirmede nitelik sorununun devam etmesine, gereksinimden fazla öğretmen mezun edilmesi de yeni istihdam sorunlarına yol açmıştır. 
1997-2007 yılları arasında uygulamada görülen eksikleri gidermek ve öğretmen yetiştirme program içeriklerini geliştirmek için YÖK'te düzenleme çalışmaları yapılmış ve 2007-2008 öğretim yılından itibaren uygulamaya konulmuştur.2007 programı incelendiğinde; VI. yarıyılda "Okul Deneyimi"; VII. Ve VIII. yarıyıllarda beşer kredilik "Öğretmenlik Uygulamaları" yer almaktadır. Ancak bu uygulamaların nasıl ve ne kadarının kent okullarında, ne kadarının birleştirilmiş sınıflı köy ilköğretim okullarında yapılacağı açık değildir.

Birleştirilmiş sınıflı köy ilköğretim okullarında görev alacak öğretmen adaylarının yetiştirilmesi açısından 2007 programında yer verilen ikişer kredilik VII. yarı yıldaki "Türk Eğitim Sistemi ve Okul Yönetimi” dersi ile VI. yarıyılda yer alan "Topluma Hizmet Uygulamaları" dersleri önemli bir gelişmedir.

Türkiye'de bugün ilköğretim bölümü sınıf öğretmenliği programını bitirenler, sınıf öğretmeni olarak atanabilmek için Kamu Personeli Seçme Sinavina (KPSS) katılmak ve 100 üzerinden 70 ve üzerinde bir puan almak durumundadır. KPSS'de başarı gösterenler arasından ilan edilen kontenjan kadar aday, başarı sırası ve tercih edilen yer dikkate alınarak MEB tarafindan ataması yapılmaktadır. Ancak atananların pek çoğu köy okullarında staj yapmadan, köy yaşantısından yoksun olarak birleştirilmiş sınıflı köy ilköğretim okullarında göreve başlamaktadırlar.

Özben (1997) "Birleştirilmiş Sınıf Uygulamalarında Karşılaşılan Sorunlar" konulu araştırmasında, araştırmaya katılan öğretmenlerin yaklaşık \%84'ü öğretmenlik eğitimleri sırasında birleştirilmiş sınıf uygulamaları konusunda yeterli staj çalışması yapılmadığını, aynı şekilde mezun olunan öğretim kurumunda, birleştirilmiş sınıfların çalışmaları ve idaresi ile ilgili yeterli bilgi ve beceri kazandırılmadığg konusunda görüş belirtmişlerdir.

Dal, 2004'de tamamladığ1 "Müdür Yetkili Öğretmenlerin Stres Kaynakları" konulu çalışmasında ise, "sınıfların birleştirilmesiyle oluşan gruplarda farklı bilgi, yaş ve deneyim düzeyindeki ögrencilerin bir arada bulunmasl" müdür yetkili öğretmenlerin sınıfları yönetmesinde ve disiplini sağlamada büyük problem oluşturduğunu belirtmiştir (Dal,2004, s.77). Aynı çalışmada müdür yetkili öğretmenlerin mesleki deneyimleri arttıkça, birleştirilmiş sınıf öğretimiyle ilgili stres kaynaklarının düştüğü belirtilmektedir.

İlgili araştırmalarda da belirtildiği gibi, birleştirilmiş sınıflı köy ilköğretim okullarında göreve başlayan öğretmenler eğer köy kökenli değiller ise ilk kez köyde yaşamaktadırlar. Çünkü eğitim fakülteleri çoğunlukla (pek azı günübirlik köy stajına yer verebilmektedir) öğretmenlik staj uygulamalarını kent ilköğretim okullarında yapmaktadırlar. Öğrenim ortamı ile gerçek iş ortamı arasındaki bu farklılık onlarda bir şaşkınlık ve alt 
üst oluş ve bozulma yaratmaktadır. Bunu önlemek için öğretmen adaylarına köy stajı yaptırılmalıdır. Programa konması planlanan köy staj uygulamaları günübirlik köye gidip dönülerek yapılmamalıdır. Bu uygulamaların amaca uygun olması için öğretmen yetiştiren üniversitelerin uygulama köyleri olmalı öğrenciler uygulama süresince köyde kalarak köyü yaşayarak köy okulunda staj uygulamalarını tamamlamalıdırlar. Öğretmen adaylarının, uygulama sonrası köy okulundan kalıcı öğrenmelerle, deneyimlerle ve iyi duygularla güven içinde dönmeleri sağlanmalıdır.

\section{Birleştirilmiş Sınıflarda Öğretimin Nedenleri}

Kırsal bölgede görev yapan pek çok eğitimci için, birleştirilmiş sınıflarda öğretim, bir deney ya da yeni bir eğitimsel eğilim ya da yönelim değildir. Tam tersine bir bölgedeki ekonomik ve coğrafi şartların gerektirdiği bir zorlamadir.

Türkiye'de pek çok yazar (Binbaşığlu, 1999; Fidan,1987; Tekışı,1989; Şahin,Ç.2007; Köksal, 2006; Taşdemir, 1997; Öztürk, 2005); "Nüfusu az olan kırsal bölgelerde, özellikle köylerde öğrenci mevcudunun azlığı, öğretmen sayısı ve derslik yetersizliği nedeniyle ilköğretim okulu 15.sınıflarında farklı düzeylerdeki birden fazla sınıfın birleştirilerek bir grup oluşturulup bir öğretmen tarafından yetiştirilmesine birleştirilmiş sınıf öğretimi denir" (Mıhçı ve Tekışık 1966) tanımında birleşmektedirler.

Öğretmen, öğrenci ve derslik azlığını birleştirilmiş sınıflarda öğretimin temel nedenleri olarak gören bu tanıma katılmakla birlikte, günümüzde daha başka nedenlerle ve özellikle gelişmiş ülkelerde pedagojik gereksinimler nedeniyle de birleştirilmiş sınıf uygulamalarının yapılmakta olduğu bilinmektedir.

Örneğin, UNESCO'nun 2005 Herkes İçin Eğitim (EFA) raporunda birleştirilmiş sınıflarda öğretimin nedenleri on başlık altında ele alınmıştır (Little, 2004). Kuşkusuz yukarıda sözü edilen öğretmen, okul ve öğrenci azlığ1 gibi bildik nedenler, EFA raporunun öne sürdüğü birleştirilmiş sınıflarda öğretimin nedenleri arasında ve en başta yer almaktadır. Raporda ele alınan on başlığın yedisi;

1.Az nüfuslu bölgelerdeki okullarda bütün sinıfların bir ya da iki öğretmen tarafindan okutulması,

2.Az nüfuslu bölgelerdeki okullarda bazı öğretmenlerin birleştirilmiş sınıflarda, bazılarının normal sınıflarda öğretim yapması,

3.Önceleri normal öğretim yapılan bölgelerdeki okulların öğretmen ve öğrenci sayılarında azalma,

4.Nüfusun artması ve buna bağlı olarak okul ve derslik gereksinimin artması fakat yeterli sayıda öğretmen ve dersliğin olmaması, 
5.Bazı velilerin çocuklarını, daha popüler (başarılı) olduğunu düşündügü okullara götürmesi sonucu daha az popüler (başarılı) olan okullarda öğrenci ve öğretmenlerin var olan sayılarında azalma olması,

6.Bir sınıfa kabul edilen öğrencilerin sayılarının resmi sınıf normu sayılarına çok geçmesi nedeniyle bir sınıfın bazı öğrencilerinin, bir diğer sınıfın öğrencileri ile birleştirilmesi zorunluluğu,

7.Gezici okullar uygulaması nedeniyle farklı yaş ve sınıflardaki öğrencilerin bir arada okutulma zorunluluğu gibi öğrenci karakteristikleri ile ilgili iken; ikisi,

8.Yeterli sayı ve nitelikte öğretmenin olmaması göreve gelmeyen öğretmenlerin yerine öğretmen bulunamaması,

9.Yetiştirilen öğretmen sayısı normal öğretim yapmak için yeterli olmasına karşın, çeşitli sebeplerle uygulamada öğretmen sayısının daha az olması gibi ögretmen karakteristikleri ile ilgilidir.

10. Onuncu başlık ise, bazı okulların genellikle genel bir eğitim programının parçası ve eğitim sistemindeki pedagojik reform gibi sebeplerle öğrencilerini normal öğretimden ziyade birleştirilmiş sınıf olarak düzenlemesidir.

Daha açık bir ifade ile on başlıktan dokuzu öğretmen ve öğrenci kaynaklı gerekliliği vurgularken, bunlardan farklı olarak bir tanesi öğretmen ve politika belirleyicilerin bilinçli seçimini yansıtmaktadır. Buna göre, eğitimin niteliğinin nasıl değiştirilip, geliştirilebileceğine yönelik öğretmen ve politika belirleyicilerinin bilinçli bir seçimi ile de birleştirilmiş sınıflarda öğretim yapılabilmektedir. Onuncu başlıkla ilgili uygulamalar daha çok gelişmiş ülkelerde görülmektedir.

\section{Birleştirilmiş Sınıflı Köy İlköğretim Okullarında Eğitim-Öğretim}

Birleştirilmiş sınıflarda öğretmenlik yapmak, normal öğretim yapan bağımsız sınıflara göre daha zordur. Bu zorluk tek öğretmenli bileştirilmiş sınıflı köy ilköğretim okullarında daha da zordur. Çünkü bu okuldaki öğretmen, aynı zamanda müdür yetkili olarak okul yöneticisidir. Dolaysıyla bir taraftan zorunlu öğrenim çağına girenleri okula kaydetmek, okulu öğretime hazırlamak, eğitim için gerekli araçları sağlamak, demirbaşları kaydetmek resmi yazışmaları yapmak gibi yönetsel işleri yaparken, diğer taraftan okuldaki öğrencilerin öğretmenliğini yapmak, öte yandan da köyün ve köylünün sorunlarına karşı duyarlı davranarak sorunların çözümünde köylüye önderlik etmek gibi görev ve sorumlulukları yerine getirmek zorundadir.

Tek derslikli ve tek öğretmenli beş sınıflı ilköğretim okullarında sınıfların nasıl birleştirileceği, derslerin nasıl okutulacağı bilimsel olarak, 
Florida Üniversitesinde köy okullarında eğitim öğretim meseleleri üzerine Prof. Wofford'un nezaretinde seminer çalışmaları ve incelemeler yapmak üzere 19 Ekim 1952'de bir yıllığına Amerika'ya giden grubun seminer çalışmalarıyla ilgili raporu (Birleştirilmiş Sınıflı Köy Okulları Program Taslağı)unda yer almıș(MEB,1955.s35) ve bu tarihten sonraki program çalışmalarında (1962 İlkokul Program Taslağı; 1968 İlkokul Programı) birleştirilmiş sınıflarda öğretim konusunun düzenlenmesine temel oluşturmuştur. Buna göre; tek dersaneli, bir öğretmenli ve beş (5) sinıflı köy okullarında; birinci, ikinci ve üçüncü sınıf öğrencileri birleştirilerek A grubunu; dördüncü ve beşinci sınıf öğrencileri birleştirilerek B grubunu oluştururlar. A ve B grubunu aynı öğretmen okutur (MEB,1952; Karagöz,1966; MEB,1968; Köksal, 2006). Öğretimi kolaylaştırmak ve öğretmene zaman kazandırmak için bazı dersler gruplaştırılarak mihver dersler oluşturulmuştur. Örneğin; Tarih, Coğrafya ve Yurttaşlık Bilgisi dersleri birleştirilerek sosyal bilgiler; Fizik,Kimya, Biyoloji dersleri birleştirilerek Fen ve Teknoloji (Fen Bilgisi) gibi mihver dersler oluşturulmuştur.

Hayat Bilgisi A grubunun mihver dersidir. B grubunun mihver dersleri ise, Sosyal Bilgiler ile Fen ve Teknoloji dersleridir. Türkçe, Matematik, Resim Müzik, Beden Eğitimi gibi ifade ve beceri derslerinde ele alınacak konuların A grubunda Hayat Bilgisi, B grubunda Sosyal Bilgiler ile Fen ve Teknoloji derslerinin temaları ile ilișkili olmasına, ünite konularının öğrenilmesine yardım etmesine dikkat edilmelidir (MEB, 1968, 2004a, 2004b, 2004c ve MEB, 2006).

2005-2006 öğretim yılından itibaren birleştirilmiş sınıflı ilköğretim okullarında Hayat Bilgisi 1. sinıf (I. Y11) temaları, Sosyal Bilgiler ile Fen ve Teknoloji derslerinde 4. sınıf (I.yıl) üniteleri olarak uygulamaya konmuştur. Uygulama dönüşümlü olarak aşağıdaki şekilde devam etmektedir (Köksal, 2006).

Öğretim Y1lı Hayat Bilgisi Programı Sosyal Bil.-Fen ve Tek. Programları
$2005-2006$
1. Sinif (I. Y11)
4. Sinif (I. Y11)
$2006-2007$
2. Sinif (II. Y11)
5. Sinif (II. Y11)
$2007-2008$
3. Sinif (III. Y11)
4. Sinif (I. Yil)
$2008-2009$
1. Sinif (I. Yil)
5. Sinif (II. Y11)
$2009-2010$
2. Sinif (II. Yil)
4. Sinif (I. Yil)

Tek derslikli ve tek öğretmenli beş sınıflı ilköğretim okullarında birleştirilmiş sınıf okutan öğretmen, "A grubu" Hayat Bilgisi temaları ile "B 
grubu" Sosyal Bilgiler ve Fen ve Teknoloji ünitelerini tek bir grup olarak ele almalıdır.

İki derslikli ve iki öğretmenli okullarda A grubunu bir öğretmen, B grubunu diğer öğretmen okutur. A ve B grubundaki öğrencilerin sayıca birbirinden çok farklı olması durumunda A grubundaki üçüncü sınıf öğrencileri de $\mathrm{B}$ grubu öğretmeni tarafından okutulabilir. Bu durumda $\mathrm{A}$ grubundan alınan üçüncü sınıf öğrencileri için üçüncü yıl temaları işlenir.

Üç derslikli ve üç öğretmenli okullarda, birinci sınıf bağımsız bir öğretmen tarafından, ikinci ve üçüncü sınıfların birleştirilmesinden meydana gelen grup ikinci öğretmen, dördüncü ve beşinci sinifların birleştirilmesinden meydana gelen grup da üçüncü öğretmen tarafından okutulur. Bu durumda ikinci ve üçüncü sinıfları okutan öğretmen, I.yılı hesaba katmadan, ikinci sinıftan başlayarak II. yıl ve III. yıl diye devam etmelidir. Birinci sınıfı okutan öğretmen ise, sadece I. yıl ünitelerine göre çalışmalarını planlamalıdır.

Birleştirilmiş sınıflarda, öğrenme ve öğretme ortamında, öğrencilerin ilgi duydukları ünite konularında derinlemesine çalışmalarına olanak sağlayan ilgi kümeleri ile ifade ve beceri derslerinde öğrencilerin hazır bulunuşluk düzeylerine uygun olan düzey (seviye) kümeleriyle çalışma önemli bir yer tutar.

\section{İlgi Kümeleri (İlgi Grupları)}

Ünite konuları işlenirken öğrenci ilgilerinden yararlanılabilir. Öğrencilerin ilgi duydukları konular üzerinde ayrıntılı ve derinlemesine çalışmalarına olanak verilmelidir. Aynı konuya ilgi duyan öğrenciler ilgi kümesi oluşturarak çalışmalarını hem bireysel hem de küme olarak sürdürebilirler. Küme çalışmalarının eğitsel bakımdan verimli olabilmesi için ilgi kümesindeki öğrenci sayısı 3-7 arasında olmalıdır. Küme çalışmalarında öğrencilerin yıl boyunca küme başkanı, küme sözcüsü, küme üyesi gibi değişik rolleri üstlenmelerine özen gösterilmelidir(Karagöz,1966). Öğrenciler küme içinde kendi konularını hazırlanarak bireysel raporunu oluşturur. Bireysel raporların birleştirilmesiyle küme raporu oluşturulur. Küme raporlarının tamamlanıp sınıfa sunulmasından ve sınıfça tartışılıp değerlendirilmesinden sonra küme raporları birleştirilerek ünite raporu oluşturulmalıdır. Sınıfın uygun bir yeri ünite köşesi olarak düzenlenerek öğrencilerin ünite süresince yaptıkları etkinlikler, resim, maket, ders araç gereçleri ünite raporuyla birlikte sergilenmelidir. Böyle bir etkinlik öğrencilerin yeni ünite konularına ve ürün temelli yeni öğrenme etkinliklerine güdülenmelerini sağlar (MEB, 2000; Öztürk, 2005). 


\section{Seviye Kümeleri (Düzey Grupları)}

Seviye kümeleri; belli bir bilgi ve beceri alanında birbirine yakın düzeyde bulunan öğrencilerin öğretim amaciyla birlikte çalışmak için oluşturdukları kümedir. (Fidan ve Baykul,1997).

Birleștirilmiş sınıflarda farklı düzeydeki öğrencilerin aynı derslikte sürekli birlikte ders yapıyor olmaları bu sınıflarda grup çalışmalarını zorunlu kılmaktadır. Türkçe, Matematik, Resim Müzik, Beden Eğitimi gibi ifade ve beceri derslerinde bilgi ya da beceri bakımından aynı düzeyde bulunan öğrencilerin eğitim-öğretim amacıyla bir araya toplanmasından meydana gelen kümedir. Birleştirilmiş sınıflarda seviye kümeleri oluştururken öğrencilerin sınıf ya da okula geliş yıllarına bakılmaz. Seviye kümeleri oluşturmada tek ölçüt, öğrencilerin aynı düzeyde olmalarıdır. Buna göre, A grubunda ikinci yılın bazı öğrencileri, üçüncü yılın bazı öğrencileri ile aynı düzeyde okuyabildikleri durumda onlarla birlikte bir okuma seviye kümesi oluşturulabilir(Karagöz,1966). Aynı şekilde matematik dersinden ileri görülen birinci sınıftan birkaç öğrenci ile, matematik dersinden geri kalmış olan üçüncü sınıf öğrencileri bir kümede toplanabilir(MEB,2000; Erdem, 2004; Köksal,2006). Kümedeki öğrenci sayı sınırlaması olmaksızın sayıyı aynı düzeydeki öğrenciler belirlemektedir. Öğretmen, sınıfındaki öğrencileri test ve benzeri yöntemlerle düzeylerini belirlemiş olsa bile, seviye kümelerini oluşturmak sanıldığı kadar kolay değildir.

Her veli çocuğunu okula gönderirken başarılı olmasını ister ve bekler. Öğrenciler için de durum aynıdır. Hiçbir öğrenci okulda başarısız bir öğrenci olarak tanınmayı istemez. Öğrenci ve veliler arasında tembeller-çalışkanlar ayrımının yapılmasını önlemek ve öğrencilerin kendi düzeylerindeki grupla çalışmaya güdülemek için öğrencileri gruplara ayırmadan önce öğrencilerle ve öğrenci velileriyle görüşerek okulun amacının, her öğrenciyi kendi güçleri ve mevcut yetenekleri içinde yetişmelerini sağlamak olduğunu, böylece onları kendine, ailesine, topluma ve insanlık dünyasına yararlı insan olarak yetiştirmek oluğunu; her öğrencinin başarılı olmak için kendi gücüne ve olgunluk seviyesine göre çaba ve gayret gösterebildiği belirtilerek çocuğun içinde bulunduğu grubun aynı öğrenme gücündeki öğrencilerden oluştuğu bu nedenle aynı güçteki öğrencilerin birlikte daha kolay ve daha iyi öğreneceği açıklanmalıdır. Böyle bir veli öğretmen, öğrenci görüşmesi, hem veliler arasında bir hoşnutsuzluğun oluşmasının, hem de daha az başarılı öğrenciler arasında küsme, içe kapanma, utanma ve aşağılık duygusuna kapılmalarını önüne geçilmiş olur. Ayrıca öğrenciler kendi hızlarında, kendi güçlerinde öğrenerek gruplarını atlamaları ve yaşlarına uygun sınıflara ulaşmaları sağlanmış olur(MEB, 1968; Tekışık, 1989).

Birleştirilmiş sınıflarda öğretimin başarılı olması için, bu okullarda; ilgi ve seviye kümeleriyle çalışmanın yanında, öğretmenin hazırlı̆̆ı, planlı 
çalışması, ders işleme yöntemi (derslerin ve sınıfların gruplandırılması), çalıșma ortamının düzenlenmesi, öğrencilerin kendi kendilerine çalıșması, öğretmenli ve ödevli derslerin etkili yürütülmesine bağlıdır.

\section{Birleştirilmiş Sınıflarda Ödevli Kendi Kendine Çalışma:}

Birleştirilmiş sınıflarda öğretmen bir taraftan öğretmenli ders saatinde öğrencilerin başarısı için eğitim öğretim etkinliğinde bulunurken, öte taraftan ödevli sınıfın kendi kendine çalışarak başarılı olması için öğrencileri bu saatlerde hangi konular üzerinde ne şekilde meşgul olacakları önceden kestirilmiş ve onlara sözlü ve yazılı açıklamalarla anlatılmış olması gerekir(Öztürk, 2005).

Ödevli sınıf ya da grubun kendi kendilerine yapacakları çalışmalarda başarılı olmaları için öncelikle öğrencilerin öğrenmeye ilişkin okuma, yazma ve hesaplama gibi temel becerileri öğrenmiş olmaları gerekir(Karagöz,1966). Öğrenci anlamlı bir okuma becerisi kazanmadan ya da diğer bir deyişle okuduğunu anlamadan, anladıklarını, duygu ve düşüncelerini yazı ile ifade etme becerisi kazanmadan; artma, eksilme, katlama ve üleşme gibi eylemleri gerektiren dört işlem becerilerini kazanmadan ödevli derslerde kendi kendine başarı sağlaması beklenemez. Öğretmene düşen görev öncelikle öğrencilerine bu temel becerileri kazandırmaktır. Öğretmen, temel ve gerekli becerileri kazandırırken öğrencilerin bireysel farlılıklar gösterebileceği gerçeğini göz önünde bulundurarak özellikle gereksinimi olan öğrencilere bireysel rehberlikte bulunmalidir( MEB, 2005a, 2005b, 2005c).

Kendi kendine çalışma saatlerinde çocukların nasıl çalışacakları öğretmen tarafından iyice açıklanmalıdır. Çalışma konuları, ödevler; "çalışın”, “yazın”, "okuyun”, problemleri çözün” gibi emir şeklinde ve genel mahiyette değil, belli, açık ve sınırlı bir şekilde olmalıdır.

Öğrenciler;

- Ne yapacaklarını,

- Niçin yapacaklarını,

- Nasil yapacaklarını,

- Hangi kaynak, araç ve gereçlerden yararlanacaklarını kesin ve açık olarak anlamış olmalıdırlar. Ancak birleştirilmiş sınıflardaki öğretimde en büyük sorumluluk öğrencinin kendisine düşmektedir.

İlköğretim programında özellikle birleştirilmiş sınıflarda kendi kendine çalışmalarla ilgili olarak yukarıdaki genel açıklamaların yanı sıra şu esasların da göz önünde bulundurulması istenmektedir(MEB,1968).

- Çocuklar; 
1. Bilginin yerini saptamak,

2. Bulunan bilgileri yazmak,

3. Sanat ve iş araçlarının kullanılmasını öğrenmek,

4. İlgi kümelerinin çalışma şekillerini öğrenmek,

5. Seviye gruplarının çalışma şekillerini öğrenmek gibi, kendi kendilerine çalışabilme alışkanlıkları kazanmalı ve geliştirilmelidir.

- Kendi kendine çalışmalar, çocuklar için önemli ve okul çalışmalarının ayrılmaz bir parçası olmalıdır.

- Kendi kendine etkinlikler, çocukların eğitim amaçlarını gerçekleştirecek nitelikte olmalıdır.

- Kendi kendine yapılacak işler, çocuklar tarafından benimsenmeli ve onların işbirliği ile planlanmalıdır.

- Kendi kendine çalışmada başarılı olmak için öğrencilerin şu temel becerileri de kazanmaları gerekir(Karagöz,1966; MEB,1968).

a- Harita, sözlük, ansiklopedi, indeks, fihrist ve bunlara benzer kaynaklar kullanmayı öğrenmek,

b- Kütüphaneden, sınıf ve okul kitaplığından nasıl yararlanılacağını öğrenmek,

c- Resim, şekil gibi görsel araçlardan bilgi edinmenin yollarını öğrenmek,

d- Gözlem, deney, inceleme, araştırma teknikleriyle elde edilen verileri düzenleyip, raporlaştırmak. Bunu sınıf seviyesine göre yapabilmek.

e- Sözlü ve yazılı raporları kümeye sunabilmek, tartışmaya katılabilmek

f- Düşüncelerini grafik, çizgi, harita, şema ve resimlerle anlatabilmek,

g- Çevre olanaklarından yararlanarak amacını ifade edebilmek,

h- Basit aletleri günlük işlerinde kullanabilmek,

i- Bilgisayar, internet, mikroskop, termometre, mercek, pusula, pil, zil gibi araçları tanımak kullanmak.

- Alıştırma/çalışma kitapları ve daha başka basılı kaynaklar, çocukları kendi kendine çalışmaya yöneltmede yararlı olabilirler.

Bir okul aile birliği toplantısı, bir gösteri, sergi, okul ya da sınıf gazetesi çıkarma, bayramlar, özel günler ve haftalar, bütün çocukların katılacağı 
çalışmalara yol açar ve kendi kendilerine çalışmalar için ayrılan zamanın yararlı şekilde geçmesini sağlar (MEB, 2000, Erdem, 2004, Köksal, 2006).

Birleştirilmiş sınıflı köy ilköğretim okullarında görevli öğretmenlerin, çoğu kez ödevli sınıfın kendi kendine çalışma saatleri için uygun etkinlik bulmada zorlandıkları görülmektedir. Oysa okulun yakın çevresi, uygulama bahçesi ve doğa zengin bir etkinlik alanıdır. Örneğin, okulun uygulama bahçesinin bir bölümü oyun alanına, bir bölümü de öğrencilerin gözlem ve deney yapabilmeleri için fen ve teknoloji dersine ayrılarak örnek deneme ekimi yapılabilir. Ekim alanları geometrik şekillerde düzenlenerek Matematik derslerinde gerçek ölçüm ve hesaplamalarda kullanılabilir. B grubu öğrencileri ile bahçeye belli ölçekte kabartma Türkiye haritası yapılarak, tarih, coğrafya, yurt ve çevre bilgisi konularının bir kısmı öğretmenli ve ödevli olarak harita üzerinde yaparak yaşayarak öğrenme yöntemiyle yapılarak kalıcı öğrenmelerin gerçekleşmesi sağlanabilir.

Miller(1991) Birleştirilmiş sınıflarda öğretimin başarısını etkileyen altı temel öğretimsel boyut olduğunu ortaya koymuştur.

Bu boyutlar:

1. Sınıfın, öğretim ortamı olarak düzenlenmesi,

2 Öğrencilerin kendi kendine öğrenmesi için öğrenci sorumluluğunu artıran bir sınıf yönetimi ve disiplininin sağlanması,

3. Öğrenci gereksinimleri üzerine temellendirilmiş bir program ve öğretimin düzenlenmesi,

4.Öğretimin niteliğini geliştiren yöntemlerin kullanılması, öğrenmesi,

5.Öğrenciyi bağımsızlık kazandırarak Kendi kendini yönetmeyi

6.Akran öğretimi olarak kategorileştirilmekte ve bu altı temel öğretimsel boyutların, öğrenciler arasında, onların kendi kendilerine öğrenmeleri için sorumluluk kazanmaları ve bunu alışkanlık haline getirmede ve aynı zamanda başka birinin öğrenmesine yardım için isteklilik kazanmalarını sağlamada önemli rol oynadığını belirtmektedir.

\section{SONUÇ}

Dünyada ve Türkiye'de uzunca bir geçmişi olan birleştirilmiş sınıflarda öğretim uygulaması, azda olsa gelişmiş ülkelerde ve yaygın olarak da gelişmekte olan ülkelerde ve bu ülkelerin özellikle kısal bölgelerinde yaygın olarak uygulanmaktadır.

Birleştirilmiş sınıf uygulaması bir ülke gerçeği olarak kabul edilmelidir. Neden olan durumlar ortadan kalkmadığ 1 sürece bu uygulamanın devam 
etmesi de kaçınılmazdır. Türkiye'de ilköğretim uzun y1llar 5 y1l olarak düzenlenmiştir. 1997 yılında 4306 sayılı yasa ile bu süre 8 yıla çıkarılmıştır. Zorunlu eğitim, bir ülkede, çocukların ve gençlerin yasal olarak devam etmekle zorunlu oldukları öğrenim süresi ve yaş grubunu ifade eder. 1948 insan Hakları Evrensel Bildirgesi'nden günümüze başlangıç düzeyinde bir eğitimi (ilköğretim veya temel eğitim) herkes için zorunlu eğitim (hak) olarak ele almış devletlere de bunu sağlama yükümlülüğünü vermişti (Kavak, 2007: 69).

Sekiz yıllık zorunlu eğitime geçilmesinin ardından, "Ĕğitimde Çăg Yakalama 2000 Projesi" ile ilköğretimde; \%100 okullaşma oranına ulaşılması aşamalı olarak birleştirilmiş sınıflarda öğretime son verilmesi, sınıf mevcutlarının 30'a indirilmesi, İlköğretimde niteliğin yükseltilmesi hedeflenmiştir. $\mathrm{Bu}$ hedeflere ilişkin politikalar belirlenmiş, gerekli planlamalar yapılmıştır (Kavak, 2007:113).

Türkiye'de bu hedeflere ulaşmak için küçük yerleşim yerlerindeki çocukları eğitim olanaklarına kavuşturmak için taşımalı eğitim, yatılı ilköğretim bölge okulu (YİBO), pansiyonlu ilköğretim okulu (PIO) gibi uygulamalar yapılmaktadır. $\mathrm{Bu}$ uygulamalarla bazı köylerde okullar kapatılmaktadır. Hâlbuki okullar bulundukları çevrenin sosyal ve kültürel merkezleridir. Köyün dışarıya açılan kapısıdır, bilime ve aydınlığa açılan penceresidir.

Birleştirilmiş sınıflarda öğretimin daha başka olumlu ve olumsuz yanları da vardır. Sınıf yönetimi, farklı sınıf düzeylerindeki öğrencilerin gereksinmelerini karşılayacak öğretim ortamları hazırlamak, uygun yöntem ve araç bulmak gibi zorlukların yanı sıra, öğrenciler kendi kendilerine ve bir başkasına nasıl yardım edeceklerini öğrenirler. Küme ve grup çalışmaları yoluyla öğrencilerin sosyalleşmesine, sorumluluk duygularının gelişmesine ve liderlik özelliklerinin ortaya çıkmasına olanak sağlaması gibi pek çok olumlu yanları bulunmaktadır.

Birleştirimiş sınıflarda öğretim uygulamasını sona erdirmek adına köy okullarını kapatma yerine, bu okulları daha etkili hale getirme yolları aranmalıdır. Öncelikle, bu okullarda görev yapacak öğretmenlerin hizmet öncesi yetiştirilmesi, çalışmakta olanların da hizmet içi eğitimle desteklenmesi, ayrıca, eğitim denetimcileri tarafindan gerekli rehberliğin yapılması ve işbaşında yetişmeleri sağlanmalidır. Aynı zamanda birleştirilmiş sınıflı okullarda görev yapan öğretmenlerin, bilgi ve deneyim yanında, köy koşullarına göre yetiştirilmesi, mesleğini sevmesi ve birleştirilmiş sınıflarda isteyerek çalışması için özendiricilerin olması yararlı olacaktır. 


\section{KAYNAKLAR}

Aksoy,N. (2008) Multigrade Schooling in Turkey:An Overview International Journal of Educational Development. 28 (2008) 218-228.

Altunya, N. (2003). Anayasa Hukuku Açısından Türkiye'de Ĕgitim Öğretim Hakkı. Ankara: Milli Eğitim Basımevi.

Aydoğan,M. (2000) Köy Enstitüleri Ille Illgili Yasalar: Cilt:I Ankara: Köy Enstitüleri ve Çağdaş Eğitim Vakfi Yayınları.

Aydoğan, M.(2007). Tonguç’a Mektuplarla Köy Enstitüsü Yılları. Ankara: Köy Enstitüsü ve Çağdaş Eğitim Vakfi Yayınları.

Baltacıŏglu, H. İ. (1939). Tek Öğretmenli ve Beş Sinıflı İlkokul. İstanbul: Maarif Matbaas1.

Başaran, İ, E. (1998). Eğitime Giriş (Yenilenmiş Dördüncü Basım). Ankara: Bilim Kitap Kırtasiye, Umut Yayım Dağıtım.

Binbaşığlu, C. (1999). Birleştirilmişs Sınıflarda Öğretim (Yenilenmiş Üçüncü Basım). Ankara: Anı Yayıncılık.

Cohen, D. (1989). First Stirrings of a New Trend: Multigrade Classrooms Gain Favor. Education Week, 9(14), 1, 13-15.

Dal, A. (2004) Birleștirilmiş Sinıflı Köy İlköğretim Okullarında Görevli Müdür Yetkili Ögretmenlerin Stres Kaynakları. Malatya: İnönü Üniversitesi Sosyal Bilimler Enstitüsü. Yayınlanmamış Yüksek Lisans Tezi.

Dirican, M.R. (1996). "Köy Enstitüleri Kanalıyla Toplum Kallınması ve Köyde Sağlık" Köy Enstitüleri: Amaçlar, Illkeler, Uygulamalar Ankara: Köy Enstitülri ve Çağdaş Eğitim Vakfi Yayınları.

Erdem, A.R. (2004). Birleştirilmiş Sinıflarda Öğretim. (İkinci Basım) Ankara. Anı Yayıncılık

Fidan, N. (1987) Birleştirilmiş Sınıflarda Öğretim. Eskişehir: Anadolu Üniversitesi Açık Öğretim Fakültesi Yayınları No:100.

Fidan,N. Baykul, Y.(1997) Birleştirilmişs Sinıflarda Öğretim Öğretmen Kılavuzu. Ankara: Ajans-Türk Matbaacılık Sanayii A.Ş.

Karagöz,Savaş (2005) Kayseri- Zincidere Köy Muallim Mektebi (19261932)' nin Türkiye'de Öğretmen Yetiştirme Tarihi İçindeki Teri. Kayseri: Erciyes Üniversitesi Sosyal Bilimler Enstitüsü Yayınlanmamış Yüksek Lisans Tezi.

Karagöz, Süleyman. (1966). I Ilkokul Program Taslă̆ı Işı̆̆ında Köy Illkokullarında Eğitim Öğretim. Ankara:MEB.Öğretmeni İşbaşında Yetiştirme Bürosu Yayınları Seri: B, Sayı: 28. 
Karasar, N.- Platteua, C. (1998). Birleştirilmiş Sınıf Uygulamaları. Eğitimde Yansimalar: IV Cumhuriyetin 75. Yllında İlkögretim I. Ulusal Seтроzуити. Ankara, 27-28 Kasım 1998. Tekışık Yayıncılık.

Kavak,Y.(2007). "Dünya'da İlköğretimin Genel Görünüşü”, Türkiye'de Okul Öncesi Eğitim ve İlköğretim Sistemi, Ankara:Türk Eğitim Derneği.

Köksal, K. (2006) Birleştirilmiş Sinıflarda Öğretim. Ankara: Pegem A Yayınc1lik.

Little, W. Angela (2004). Learning and Teaching Multigrade Settings. Paper Prepared for UNESCO 2005 EFA Monitoring Report.

MEB (1952), Köy Okullarında Birleştirilmiş Sinuflar Iç̧in Program Taslağı. Ankara: Milli Eğitim Basımevi.

MEB(1954) "Birleştirilmiş Köy Okulu Program Taslağı” Florida Grubunun Seminer Çalışmalartyla İlgili Rapou.

MEB (1968). İlkokul Programı. İstanbul: Milli Eğitim Basımevi.

MEB Komisyon (2000). İlkögretim Birleştirilmiş Sinıflar Fen Bilgisi ve Sosyal Bilgiler Ögrretmen Kılavuz Kitabı. Ankara: Milli Eğitim Basımevi.

MEB (2004a). Illkögrretim Hayat Bilgisi Dersi Öğretim Programı. Ankara: Devlet kitapları Müdürlüğü.

MEB (2004b). Illköğretim Sosyal Bilgiler Dersi Öğretim Programı. Ankara:Devlet kitapları Müdürlüğü.

MEB (2004c). Illköğretim Fen ve Teknoloji Dersi Öğretim Programi. Ankara: Devlet kitapları Müdürlüğü.

MEB(2005a)İlköğretim Sosyal Bilgiler Öğretmen Kılavuzu Kitabı.İstanbul. Devlet kitapları Müdürlüğü.

MEB(2005b). Illköğretim Fen ve Teknoloji Öğretmen Kılavuzu Kitabı. İstanbul:Devlet kitapları Müdürlüğü

MEB (2005c). Milli Eğitim Ístatistikleri (2004-2005). Ankara: Devlet Kitapları Müdürlüğü.

MEB (2006). Yeni İlkögretim Programları, Ankara: Milli Eğitim Bakanlığı Yayınları.

Mıhçı, C., Tekışık, H.H.(1966). Birleştirilmiş Sınıflı Köy Okullarında Ögretim. (Geliştirilmiş Üçüncü Basım) Ankara: Rehber Yayınları PK:429.

Miller, B. (1989). The Multigrade Classroom: A Resource Handbook for Small, Rural Schools. Portland, OR: Nortwest Regional Educational Laboratory. (ERİC Document Reproduction Service No. ED 320 719). 
Miller, B. (1991). Teaching and Learning in the Multigrade Classroom: Student Performance and Instructiönal Routines. (ERIC Document Reproduction Service No. ED \& 178).

Mulryan-Kyne.C.(2006) The Preparation of Teachers for Multigrade Teaching. Teaching and Teacher Education. Doi: 10.1016/j.tate.2006.12.003.

Muse, I., Simith, R.,ve Barker, B. (1987). The One - Teacher School in the 1980s. Las Cruces, NM: ERIC Clearinghouse on Rural Education and Small Schools. (ERIC Document Reproduction Service No.ED 287 646)

Öktem, R.(2007) Milli Ĕgitim Bakanlı̆̆ı'na Bă̆lı Birleştirilmiş Sinıflı Illkögretim Okullarında Müdür Yetkili Öğretmenlik Uygulamasında Yaşanan Sorunların Değerlendirilmes.(Ankara İli Kalecik İlçesi Örneği). Ankara Üniversitesi Eğitim bilimleri Enstitüsü Yayınlanmamış Tezsiz Yüksek Lisans Projesi.

Özben,K.(1997) Birleştirilmiş Sınıf Uygulamasında Karşılaşılan Sorunlar. Denizli: Pamukkale Üniversitesi Sosyal Bilimler Enstitüsü.Yayınlanmamış Yüksek Lisans Tezi.

Öztürk, H. İ. (2005). Birleştirilmişs Sınıflarda Öğretim. İstanbul: Lisans Yayıncilik.

Rule, J. (1983). Effects of Multigrade Grouping on Elementary Student Achievement in Reading and Mathematics. Dissertation Abstracts International ,44(3), 662. (University Microfilms No.ADG83-15672).

Şahin, Ç.(2007). Birleştirilmiş Sınıflarda Öğretim. Ankara: Pegem A Yayınc1lik.

Taşdemir, M.(2000) Birleştirilmiş Sınıflarda Öğretim. Ankara: Ocak yayınları.

T.C. Kültür Bakanlığı(1938) Köy Mektepleri Müfredat Programı. İstanbul:Devlet Basımevi.

Tekışık,,H.H.(1989). Birleştirilmiş Sinıflı Köy Okullarında Öğretim. (Geliştirilmiş Üçüncü Basım) Ankara: Rehber Yayınevi.

Tonguç, İ.H.(1947) Eğitim Yoluyla Canlandirılacak Köy. İstanbul: (İkinci basılış) Remzi Kitebevi.

Uyar, B. (2000) Tonguç'un Eğitmenleri. Ankara: Aktaş Matbaas1. 